\title{
Ambulatory hand emergency: 2 years-experience in an public university hospital center
}

\author{
Alice Carricaburu, Jordane Mouton, Iad Nseir, Roberto Beccari, Silvia Gandolfi, Isabelle Auquit-Auckbur
}

From the Departement of Plastic and Hand Surgery, Charles Nicolle University Hospital, Rouen, France

Hand emergencies represent the most frequent traumatic injuries and outpatient surgery is still improving. It will achieve $70 \%$ of total surgeries by 2022.

Our hand trauma center has been able to set up an emergency day surgery department in a university hospital center.

With this article, we would like to report the ambulatory care management and practice for hand emergencies in our university hospital center over 2 years. 892 patients suffering from hand traumas and managed in our day surgery department, were retro-spectively reviewed between January 2016 and December 2017. Patients' demographic data, anesthetic data, trauma's circumstances, medical care and surgical outcomes have been disclosed. A descriptive analysis and a statistical assessment was realized.

Cut injury was the most recorded case, followed by impactions. Tendon injuries were the most frequent $(32 \%)$, followed by fractures $(26 \%)$, and exposed joints (18\%). $13 \%$ of injuries were nil findings. Average patient care delay was 1.16 days. Mean of hospitalization was 7.5 hours. $16 / 892$ patients needing intravenous antibiotics required hospitalization. 41 complications including 27 secondary surgeries were reported.

Hospital facilities are forced to reassess their entire procedures to achieve efficiency and improvement for healthcare. Progress in outpatient surgery permits emergency management in hand surgery, improving patient cares both medically and economically.

Keywords : hand emergency ; public ; outpatient ; traumatology ; hand surgery.

No benefits or funds were received in support of this study. None of the authors have a conflict of interest.

\section{INTRODUCTION}

Hand trauma represents the first consulting cause in emergency department with a frequency of 2.142.393 hand traumas per year (1). An initial optimal patient care leads to a decrease of both public health costs and trauma consequences $(2,3)$.

Since 1979, the hand emergency department federation (FESUM) operates and accredits the emergency centers in order to improve patient care in hand traumas. In 2019, 65 centers were certified "Emergency center" (aka "SOS main" in French), providing an optimal patient care day and night for hand traumas (4).

- Alice Carricaburu ${ }^{1} \mathrm{MD}$,

- Jordane Mouton² MD,

- Iad Nseir ${ }^{1} \mathrm{MD}$,

- Roberto Beccari ${ }^{3} \mathrm{MD}$,

- Silvia Gandolfi',

- Isabelle Auquit-Auckbur ${ }^{1} \mathrm{MD}, \mathrm{PhD}$

${ }^{1}$ Departement of Plastic and Hand Surgery, Charles Nicolle University Hospital, Rouen, France.

${ }^{2}$ Departement of Orthopedic Surgery, Charles Nicolle University Hospital, Rouen, France.

${ }^{3}$ Departement of Orthopedic and Hand Surgery, Private Hospital Clinique du Cèdre, 950 rue de la Haie 76230 Bois Guillaume, France.

Correspondence : Alice Carricaburu, Departement of Plastic and Hand Surgery, Charles Nicolle University Hospital, Rouen, France.

Email : mouton.jor@gmail.com

- 2021, Acta Orthopædica Belgica.

Acta Orthopædica Belgica, Vol. 87 - 2 - 2021 
Currently, the French health care system has to decrease its costs and increase its efficiency. In this regard, development of outpatient surgery is essential.

Global activity of outpatient surgery is improving in France : it accounted the $32.3 \%$ in 2007 , the $37.7 \%$ in 2010 and the objective is to reach $70 \%$ by $2022(5)$.

In most cases, Hand surgery permits an ambulatory care. In order to allow this patient care, a Resident on-call for hand emergencies, guided by a Senior Hand surgeon, is able to take care of patients upon their arrival.

Through an initial specialized clinic exam, resident in hand surgery can coordinate patient's care in the ambulatory department. The responsible Resident and Senior surgeon, after proper medical cares, will be in charge of the patient's follow-up. In this optic, the patient will be received by the same medical staff, and residents will improve their medical education.

In addition, the development of a "delayed hand emergency" department is achievable within a university hospital center (UHC) in order to reduce the emergency flow and improve patient's care.

We would like to report a retrospective epidemiologic study of the ambulatory care management for hand emergencies in our university hospital center over the first 2 years.

\section{MATERIAL AND METHOD}

We performed a retrospective observational study on hand emergency patients treated within the new outpatient hand emergency department at Charles Nicolle UHC (Rouen, France) between the 26th January 2016 and the 31st December 2017. Patients undergone surgery during a dedicated outpatient surgery vacation, from Monday to Friday.

The study involved adults over 16 years old with eligible hand trauma for an ambulatory care. Exclusion criteria were : patients under supervision or guardianship, with pathologies requiring hospitalization (revascularization, open and complex fractures, deep infections and/or clinical contests requiring intraveinous antibiotherapy,), polytrauma patients.
The following parameters were collected :

- Demographic data : age, gender, dominant hand, employment sector

- Trauma parameters : date, number of fingers impacted, location, injury mechanism, type of accident (workplace or domestic accident)

- Patient medical history : ongoing antiplatelet treatment or anticoagulant treatment

- Patient anesthetic characteristics: physical status score (PSS), anesthetic procedure

- Surgery procedure : delay and duration of surgical procedure, number of lesions, surgical gesture performed, tourniquet duration and need, need for fluoroscopy or microsurgery equipment

- Postoperative care: analgesic treatment, antibiotic therapy, immobilization, rehabilitation, duration for cessation of work, delay to postoperative consultation, patient discharge procedure

- Postoperative complications : secondary surgery, surgery complications or anesthetic complications, leading to a standard hospitalization

Statistical review has been performed by the biostatistics service of our UHC. One analysis was performed through binomial exact test and additionally analysis of complications was performed through student's test.

\section{RESULTS}

Over this 2-years period, 892 patients have been included in our study, 8 have been excluded. Population studied included 909 surgical hands, 17 patients undergoing bilateral surgery.

Average age of patients was 38.3 years old ( $\mathrm{min}$ : 16 ; $\max : 97$; DS : +/- 16.2). 5.9\% of patients were minors $(n=52 / 892)$. Gender ratio was men :women $=3.6: 1.90 .4 \%$ of total patients were right handed $(\mathrm{n}=807 / 892)$. The dominant hand was involved in $49.4 \%$ of total cases $(n=440 / 892)$.

Among 892 patients, 52.4\% $(n=467 / 892)$ were manual workers. Workplace accidents occurred in $32.7 \%$ of total cases $(n=290 / 892)$.

In two-third of total cases, the trauma was related to a cut injury ( $n=548 / 892)$. Fractures accounted for $26.1 \%$ of total cases $(n=233 / 892)$.

Lesions facing a joint were predominant with $70 \%$ of total cases $(n=624 / 892)$, as well as the palmar lesions in $49.7 \%$ of total cases $(n=442 / 892)$. 
Table I. - Overview of trauma mechanisms

\begin{tabular}{|l|c|}
\hline Mechanism & Cases N (\%) \\
\hline Cut & $548(61,4)$ \\
\hline Fracture & $233(26,1)$ \\
\hline Crushing & $97(10,9)$ \\
\hline Tearing & $54(6,1)$ \\
\hline Sepsis & $53(5,9)$ \\
\hline Foreign substance & $26(2,9)$ \\
\hline Bite & $24(2,7)$ \\
\hline
\end{tabular}

Table II. - Location of trauma

\begin{tabular}{|l|c|}
\hline Location & Cases N (\%) \\
\hline Palmar & $443(49,7)$ \\
\hline Dorsal & $320(35,9)$ \\
\hline Facing joint & $624(70)$ \\
\hline Multiples & $129(14,4)$ \\
\hline I & $221(24,8)$ \\
\hline II & $239(26,8)$ \\
\hline III & $176(19,7)$ \\
\hline IV & $174(19,5)$ \\
\hline V & $178(20)$ \\
\hline
\end{tabular}

129 patients showed multiple wounds. The index was affected in $26.8 \%$ of total cases ( $n=239 / 892)$.

Data are summarized in Table I, II.

10 patients were under antiplatelets, 3 under oral anticoagulant treatment. No stopping and no relay treatment was required during patient care.

$84 \%$ of patients classified as ASA $1(n=752 / 892)$, $14 \%$ as ASA $2(\mathrm{n}=127 / 892)$ and $1.5 \%$ ASA 3 $(\mathrm{n}=13 / 892)$; no patient was classified ASA 4.

$98.9 \%$ of total patients have been through surgery under Loco-regional anesthesia (LRA) $(\mathrm{n}=882 / 892), 10$ under local anesthesia (LA) and 5 under general anesthesia (GA) following an LRA failure. For 5 patients, anesthesia procedure was multimodal : 3 patients benefited from a GA after LRA and 2 patients benefited from a LA after LRA (bilateral damages).

The average patient care delay was 1.16 days (DS : +/- 0.96).

The maximum waiting period before surgery was equal to 14 days ( $5^{\text {th }}$ metacarpal fracture with secondary displacement).

The average surgery duration was equal to $27 \mathrm{~min}$ (min : 3min, $\max : 139 \mathrm{~min}$ ). The tourniquet was needed in $95 \%$ of total cases $(n=846 / 892)$ during
Table III. — Panorama of discovered lesions

\begin{tabular}{|l|l|}
\hline Type of lesions & N (\%) \\
\hline Tendon damage & $288(32,3)$ \\
\hline Osteoarticular damage & $255(28,6)$ \\
\hline Sheath opening & $162(18,2)$ \\
\hline Articular exposure & $160(17,9)$ \\
\hline Nerve damage & $133(14,9)$ \\
\hline No lesions findings & $115(12,9)$ \\
\hline Soft tissue defects & $100(11,2)$ \\
\hline Sepsis or Abscess of soft tissues & $48(5,4)$ \\
\hline Arterial damage & $47(5,3)$ \\
\hline Paronychia & $22(2,5)$ \\
\hline Phlegmon & $9(1)$ \\
\hline Arthritis & $8(0,9)$ \\
\hline
\end{tabular}

$26 \mathrm{~min}$ in mean, with a maximum duration of $139 \mathrm{~min}$.

All discovered lesions and related surgery procedures are further detailed in Table III.

The average hospital stay was 7.5 hours (DS : +/$0.9)$.

Analgesics of level 1 have been prescribed for all patients (100\%); analgesics of level 2 for $98.6 \%$ of total patients $(n=880 / 892)$. No patient was discharged with analgesics of level 3.

$56,3 \%$ of patients received post-operative antibiotics.

Return to work in mean after 23.06 days (maw : 90 days).

The average delay of the first follow-up of 9,89 days (DS : +/- 6.53), in 772 patients $(86,5 \%)$.

In $82 \%$ of cases $(n=94 / 115)$, nil findings did not consult after surgery.

$1.9 \%$ of total patients $(n=17 / 892)$ were discharged benefiting of a medical transportation (light health vehicle or ambulance).

$2 \%$ of patients required a hospitalization $(n=$ $18 / 892$ ) within conventional sector after surgery, either for setting up an intravenous antibiotic therapy treatment or due to anesthetic effect (pain, cardiac dysrhythmia).

Complications were found for $4.6 \%$ of total patients $(n=41 / 892)$ and are detailed in Table IV. A revision surgery was needed in $3 \%$ of total patients $(n=27 / 892)$.

A subgroup analysis (Table V) allowed us to discover that the group showing complications was 
Table IV. - Recorded complications

\begin{tabular}{|l|c|c|c|}
\hline \multicolumn{1}{|c|}{ COMPLICATIONS } & NUMBER & $\begin{array}{c}\text { REVISION } \\
\text { SURGERY }\end{array}$ & TYPE OF REVISION SURGERY \\
\hline SECONDARY DISPLACEMENT & 4 & 3 & \\
\hline TENDON & 9 & 8 & Tenolysis \\
\hline Suture elongation & 3 & 3 & Arthrolysis \\
\hline Stiffness & 5 & 4 & \\
\hline Boutonniere deformity & 1 & 1 & Necrosectomy and full thickness skin graft, \\
\hline SKIN & 3 & 3 & Amputation \\
\hline Necrosis of skin flap & 3 & 2 & \\
\hline Retracted scars & 2 & 1 & Ingrown nail surgery \\
\hline Skin graft lysis & 1 & 0 & Matrix sterilisation \\
\hline NAIL & 2 & 2 & \\
\hline & 1 & 1 & Pseudoarthrosis cure \\
\hline Nail regrown following trans-P3 regularization & 1 & 1 & \\
\hline REGIONAL PAIN SYNDROME TYPE $\mathbf{1}$ & 8 & 0 & Amputation \\
\hline GRANULOMAS & 4 & 4 & Materials retreat \\
\hline NEUROMAS & 2 & 1 & Materials retreat \\
\hline PSEUDARTHROSIS & 1 & 1 & \\
\hline INFECTION ON IMPLANTED MATERIALS & 5 & 5 & \\
\hline Chronic infection with osseous exposition & 1 & 1 & \\
\hline Septic arthritis on materials & 3 & 3 & \\
\hline Osteitis on materials & 1 & 1 & 27 \\
\hline TOTAL & 41 & & \\
\hline
\end{tabular}

epidemiologically targeting an older population (mean : 38 years old vs 42.9 years old; $p=0,05$ ) and more frequently female gender ( $39 \%$ vs $20 \%$; $p=0,05)$. No difference between the 2 groups was found related to the lesions location. Crushing traumatic mechanism was more frequent in the group with complications ( $31 \%$ vs $9.8 \% ; p=0,00005)$. Flap surgery type was more frequent in the group showing complications ( $29 \%$ vs $10 \% ; \mathrm{p}=0,0001)$.

On anesthetic level, there was no difference between the 2 groups for the levels ASA 1 and 2, but most likely a trend for the ASA 3 with $4.8 \%$ within the group with complications vs $1 \%$ for the group without complication $(\mathrm{p}=0,06)$.

\section{DISCUSSION}

Our study is mostly composed of young adult men and manual workers, according to literature reviews related to hand traumas $(6,7)$. Workplace accidents occured for one third of patients similarly to Dubert and Angermann's series $(7,8)$.
For this population, an inappropriate initial patient care can lead to heavy professional and social consequences. An initial optimal patient care is therefore needed $(2,3)$, because unfortunately hand wounds are still too often disregarded (9).

In our sample, we discovered only $12.9 \%$ of "nil findings" hands (without any specific lesion). This shows the quality of primary clinical examination. Consequently $87.1 \%$ of all patients showed lesions requiring a specialized surgery care. This ratio strengthens the consensus established by the scientific groups (Hand Emergency Department Federation (FESUM), National Society of Emergency medicine (SFMU)), supporting the need of exploration under surgical procedure of every palmar hand and dorsal facing joint wounds (10-13). This ratio also supports the value of a quality initial clinical examination, that in our cases is conducted by formed residents in hand surgery. This number differs significantly from Dubert's series with « nil findings $»$ occurring in more than $50 \%$ of operated cases over 8 days (7). 
Table V: Analysis of complications

\begin{tabular}{|c|c|c|c|}
\hline & $\begin{array}{c}\text { Group without compli- } \\
\text { cation }(\mathrm{n}=851)\end{array}$ & $\begin{array}{c}\text { Group with complica- } \\
\text { tion }(n=41)\end{array}$ & \\
\hline Age & $38(+/-16)$ year old & $43(+/-15)$ year old & $P=0.05$ \\
\hline Gender ratio $(\mathrm{M} / \mathrm{F})$ & $675 / 176$ & $25 / 16$ & $P=0.005$ \\
\hline Delay before surgery & 1.17 days & 1.12 days & $P=0.76$ \\
\hline Palmar surface injury & $418 / 851$ & $25 / 41$ & $P=0.14$ \\
\hline Flap surgery & $88 / 851$ & $12 / 41$ & $P=0.0001$ \\
\hline $\begin{array}{r}\text { Anesthetic score : } \\
- \text { ASA } 1 \\
- \text { ASA } 2 \\
- \text { ASA } 3\end{array}$ & $\begin{array}{c}719 / 851 \\
121 / 851 \\
11 / 851 \\
\end{array}$ & $\begin{array}{c}33 / 41 \\
6 / 41 \\
2 / 41 \\
\end{array}$ & $\begin{array}{l}P=0.49 \\
P=0.94 \\
P=0.06\end{array}$ \\
\hline $\begin{array}{l}\text { Anticoagulant } \\
\text { Antiplatelet }\end{array}$ & $\begin{array}{l}28 / 851 \\
50 / 851\end{array}$ & $\begin{array}{l}2 / 41 \\
0 / 41\end{array}$ & $\begin{array}{l}P=0.82 \\
P=0.31\end{array}$ \\
\hline $\begin{array}{l}\text { Mechanism } \\
\text { - Cut } \\
\text { - Tearing } \\
\text { - Crushing } \\
\text { - Fracture } \\
\text { - Bite } \\
\text { - Foreign substance } \\
\text { - Sepsis }\end{array}$ & $\begin{array}{c}529 / 851 \\
50 / 851 \\
84 / 851 \\
219 / 851 \\
22 / 851 \\
24 / 851 \\
49 / 851\end{array}$ & $\begin{array}{c}19 / 41 \\
4 / 41 \\
13 / 41 \\
14 / 41 \\
2 / 41 \\
2 / 41 \\
4 / 41\end{array}$ & $\begin{array}{c}P=0.04 \\
P=0.31 \\
P<0.001 \\
P=0.23 \\
P=0.37 \\
P=0.44 \\
P=0.29\end{array}$ \\
\hline 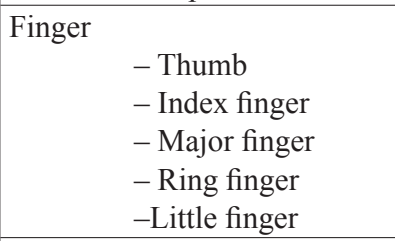 & $\begin{array}{l}211 / 851 \\
225 / 851 \\
171 / 851 \\
163 / 851 \\
170 / 851 \\
\end{array}$ & $\begin{array}{c}10 / 41 \\
14 / 41 \\
5 / 41 \\
11 / 41 \\
8 / 41 \\
\end{array}$ & $\begin{array}{c}P=0.9 \\
P=0.36 \\
P=0.21 \\
P=0.22 \\
P=0.94\end{array}$ \\
\hline $\begin{array}{l}\text { Mechanism } \\
\text { - Cut } \\
\text { - Tearing } \\
\text { - Crushing } \\
\text { - Fracture } \\
\text { - Bite } \\
\text { - Foreign substance } \\
\text { - Sepsis }\end{array}$ & $\begin{array}{c}529 / 851 \\
50 / 851 \\
84 / 851 \\
219 / 851 \\
22 / 851 \\
24 / 851 \\
49 / 851\end{array}$ & $\begin{array}{c}19 / 41 \\
4 / 41 \\
13 / 41 \\
14 / 41 \\
2 / 41 \\
2 / 41 \\
4 / 41\end{array}$ & $\begin{array}{l}P=0.04 \\
P=0.31 \\
P<0.001 \\
P=0.23 \\
P=0.37 \\
P=0.44 \\
P=0.29\end{array}$ \\
\hline $\begin{array}{c}\text { Operative revision: } \\
\text { - Phlegmon } \\
\text { - Arthritis }\end{array}$ & $\begin{array}{l}9 / 851 \\
8 / 851\end{array}$ & $\begin{array}{l}0 / 41 \\
0 / 41 \\
\end{array}$ & $\begin{array}{l}P=0.5 \\
P=0.5\end{array}$ \\
\hline
\end{tabular}

The daily flow of "hand emergencies" patients (15 to $30 \%$ of emergency surgeries) $(7,14)$, couldn't be managed by our center through the only traditional emergency department. This system allows us to practice surgery the following day after their initial consultation, in most of cases, avoiding an undue bed occupancy the day before surgery and the night later. This point permit to improving the efficiency of patient care (13).

In addition, before the establishment of this new management protocol, hand trauma patients were hospitalized while waiting for surgery in emergency operating rooms, which were frequently fully occupied by emergencies related to other specialties. This pushed backwards hand traumas into last positions on the waiting list, with a delay that might be extended to 24 up to 72 hours. Unfortunately, this old procedure is sometimes still conducted during weekends where patients are initially sent to the general emergency department. However, during weekend, the possibilities to reconvene patients for Monday ambulatory surgery 
timeslot is previewed simplifying patient's care procedures. The success of a rapid and efficient management in an ambulatory department is based both on a specific dedicated organization as well as on surgery/anesthetic cooperation (15). This ambulatory management is common within private structures. Creation of such a structure within a public hospital was only possible thanks to the will and coordination of various actors. Junior doctors are essential in every step of hand patient care (preliminary exploration, pre- and post-operative consultations, surgical intervention) and this system allows a quality training for future hand surgeons.

In our study, the age of the population was not a limited factor for outpatient care : 65 years old patients accounted for $7.5 \%$, including the oldest patient of 97 years. According to the SFAR (French Society of Anesthesia and Reanimation), old age does not represent a contraindication to outpatient treatment as aged patients' population is expected to rise $(16,17)$. In addition, with a specific interest in elderly, outpatient care also seems to reduce impact of postoperative behavior disorders compared to a conventional hospitalization (15).

Postoperative analgesia remains the keypoint of unscheduled outpatient care for patients, especially in orthopedic surgery and hand surgery $(18,19)$.

In our study, we haven't noticed any readmission or emergency consultation for postoperative pain. The systematic association of analgesics of level 1 and level 2 effectively reduce postoperative pain and consequently increased satisfaction rate on patients (20), thus, we believe that prescriptions of postoperative analgesics level 1 and 2 should be immediately delivered after examination at the emergency department (ER), in order to increase compliance and patients' satisfaction (21).

According to literature (7) septic hand wounds can be managed in an ambulatory mode. Only abscesses, simple arthritis and early stage were admitted in outcare patient care. The most serious infections were hospitalized in conventionnal department. We manage perioperative antibiotic treatment relying on the consensus of the SFAR (French Society of Anesthesia and Reani-mation) emanating from extrapolations from orthopedic surgery and Dumontier $(22,23)$.
Thus all surgery needing material implantation (resorbable or non-resorbable) or arthrotomy beneficiated from $2 \mathrm{~g}$ Cefazolin or Clindamycin in case of allergies as antibiotic prophylaxy. This work shows us a surpresciption of antibiotics. We since have been very cautious not to overprescribe antibiotics treatments in order to limit the emergence of resistant bacterial strains $(24,25)$. In this study, we had $0,56 \%(n=5 / 892)$ of septic complications, not far from global rates found in literature (22). We noticed that crushing mechanisms, most of all leading surgeons to practice flap surgery, in order to cover soft tissue defects, were strongly associated with septic complications. Therefore, patients undergoing surgeries with major skin contusion as well as ones requiring flap surgery, were early examined at day 2.

Outpatient surgery presents lower costs compared with conventional hospitalization, because of absence of overnight stay. In the last two decades, public authorities have encouraged healthcare organizations to increase the outpatient surgery activity, especially since the 2010 hospital instruction law (25). For economic considerations it is not surprisingly that UK surgeons realize the $80 \%$ of surgeries through outpatient protocols $(26,27)$. In contrast public French hospitals are in late on ambulatory health care.

\section{CONCLUSION}

This study demonstrates that a top-quality and a rapid outpatient care of hand emergencies is achievable in a public university institution, under the conditions to have sufficient resources as dedicated structures and a multidisciplinary involvement.

Hospital facilities are forced to reassess their entire procedures towards the double objective of efficiency and improvement on healthcare. Progress in outpatient surgery permits emergency management in hand surgery, improving patient cares both medically than economically.

\section{REFERENCES}

1. Fédération des Services d'Urgences de la Main. Livre Blanc 2018. 
2. Harrison W, Newton AW, Cheung G. The litigation cost of negligent scaphoid fracture management. Eur J Emerg Med Off J Eur Soc Emerg Med 2015 ; 22 : 142-3.

3. Rosberg H-E, Carlsson KS, Dahlin LB. Prospective study of patients with injuries to the hand and forearm : costs, function, and general health. Scand J Plast Reconstr Surg Hand Surg Nord Plast Foren Nord Klubb Handkirurgi $2005 ; 39: 360-9$.

4. Jean-Louis Ducassé, Claire Hault, Flore Matthieu, Thomas Richard. "Enquête qualitative préalable à la définition d'une enquête nationale sur les urgences hospitalières » 2013.

5. ORCA Chirurgie ambulatoire ARS IDF n.d. http://www. orca-chirurgie-ambulatoire-ars-idf.fr/127-1-objectif-de-lachirurgie-ambulatoire-est-maintenant-de-70-pour-2022. html (accessed January 27, 2019).

6. Schuind F, Dap F, Farcot JM, Jost H, Foucher G. La chirurgie de la main en pratique ambulatoire. Ann Chir Main 1986 ; 5 : 122-8.

7. Dubert T, Allieu Y, Bellemère P, Egloff D, Nonnenmacher J, Baudet J, et al. (Eight days of hand emergencies. Report of the audit carried out at the FESUM centers from June 3 to June 9, 2002). Chir Main $2003 ; 22: 225-32$.

8. Angermann P, Lohmann M. Hand and wrist injuries. A study of 50,272 injuries. Ugeskr Laeger 1995 Feb 6; $157(6): 734-7$.

9. Mouton J, Houdre H, Beccari R, Tarissi N, Autran M, Auquit-Auckbur I. Surgical exploration of hand wounds in the emergency room : Preliminary study of 80 personal injury claims. Orthop Traumatol Surg Res. 2016 Dec; 102(8) : 1009-1012.

10. SFMU. 12eme Conférence de Consensus : Prise en charge des plaies aux urgences. 2005. n.d.

11. SFMU. Conférences : session commune Sofcot/Sfmu. Les traumatismes mineurs du poignet et de la main. 2011. n.d.

12. FESUM, la SOFCOT, le GEM, la SFMU et la SOFCPRE. fiche examen initiale plaie main FESUM.

13. Amsallem L, Pierrart J, Werthel J-D, Delgrande D, Bihel T, Sekri J, et al. Hand injury without any deficit: Is systematic surgical exploration justified? Hand Surg Rehabil 2019; 38 : 20-3.

14. Kehlet H, Wilmore DW. Evidence-based surgical care and the evolution of fast-track surgery. Ann Surg 2008; 248 : 189-98.

15. Claude Kenesi , Emmanuel Masmejean. Les urgences main en France. Un important défi de santé publique. Bulletin Académie Nationale de Médecine $2004 ; 188$; 5 ;793-801.

16. Prise en charge anesthésique des patients en hospitalisation ambulatoire. SFAR - Société Fr D'Anesthésie Réanimation
2015. http://sfar.org/prise-en-charge-anesthesique-despatients-en-hospitalisation-ambulatoire/ (accessed June 1, 2017).

17. Ahlbom A, Drefahl S, Lundström H. (The aging population. Continuing increase of average longevity is a controversial and exciting question). Lakartidningen 2010 ; $107: 3048-51$.

18. Vaupel JW. Biodemography of human ageing. Nature 2010 ; 464 : 536-42.

19. Chung F, Ritchie E, Su J. Postoperative pain in ambulatory surgery. Anesth Analg 1997 ; 85 : 808-16.

20. Rawal N, Hylander J, Nydahl PA, Olofsson I, Gupta A. Survey of postoperative analgesia following ambulatory surgery. Acta Anaesthesiol Scand 1997 ; 41 : 1017-22.

21. Rawal N, Macquaire V, Catalá E, Berti M, Costa R, Wietlisbach M. Tramadol/paracetamol combination tablet for postoperative pain following ambulatory hand surgery : a double-blind, double-dummy, randomized, parallel-group trial. J Pain Res $2011 ; 4$ : 103-10.

22. Lemarie M, Compère V, Fourdrinier V, Lignot $S$, Legrand L, Marguerite C, et al. Évaluation de l'impact d'une prescription d'antalgiques réalisée lors de la consultation d'anesthésie sur l'incidence de la douleur à domicile en chirurgie ambulatoire orthopédique. Ann Fr Anesth Réanimation $2011 ; 30$ : 883-7.

23. Dumontier C, Lemerle J. (Antibioprophylaxy in hand surgery: toward a professional consensus). Chir Main $2004 ; 23$ : 167-77.

24. Antibioprophylaxie en chirurgie et médecine interventionnelle (patients adultes) - La SFAR. Société Fr D'Anesthésie Réanimation 2018. https://sfar.org/antibioprophylaxie -en-chirurgie-et-medecine-interventionnelle-patientsadultes-2017/ (accessed January 27, 2019).

25. Cars O, Mölstad S, Melander A. Variation in antibiotic use in the European Union. Lancet Lond Engl 2001 ; 357 : 1851-3.

26. Vander Stichele RH, Elseviers MM, Ferech M, Blot S, Goossens H. European Survaillance of Antibiotic Comsuption (ESAC) Project Group. Hospital consumption of antibiotics in 15 European countries : results of the ESAC Retrospective Data Collection (1997-2002). J Antimicrob Chemother 2006 ; 58 : 159-67.

27. Instruction DGOS/R3 no 2010-457 du 27 décembre 2010 relative à la chirurgie ambulatoire : perspectives de développement et démarche de gestion du risque. 2011.

28. Twersky RS. Ambulatory surgery update. Can J Anaesth J Can Anesth 1998 ; 45 : R76-90.

29. Vaghadia H. Outcomes in outpatients - what occurs outside? Can J Anaesth J Can Anesth 1998 ; 45 : 603-6. 